\title{
Post-vaccination anti-HBs testing among healthcare workers: More economical than post-exposure management for Hepatitis B*
}

\author{
Camila Lucas de Souza ${ }^{1}$ \\ (D) https://orcid.org/0000-0002-1779-5909 \\ Thaís de Arvelos Salgado ${ }^{2}$ \\ (1) https://orcid.org/0000-0002-7652-4367 \\ Tatiana Luciano Sardeiro ${ }^{3}$ \\ (1D) https://orcid.org/0000-0001-5265-8195 \\ Hélio Galdino Junior ${ }^{4}$ \\ (1D) https://orcid.org/0000-0002-5570-8183 \\ Alexander Itria ${ }^{5}$ \\ (iD) https://orcid.org/0000-0001-7500-0230 \\ Anaclara Ferreira Veiga Tipple 4 \\ (D) https://orcid.org/0000-0002-0812-2243
}

Objective: to compare the direct cost, from the perspective of the Unified Health System, of assessing the post-vaccination serological status with post-exposure management for hepatitis B among health care workers exposed to biological material. Method: cross-sectional study and cost-related, based on accident data recorded in the System of Information on Disease Notification between 2006 and 2016, where three post-exposure and one pre-exposure management scenarios were evaluated: A) accidents among vaccinated workers with positive and negative serological status tests for hepatitis $B$, exposed to known and unknown source-person; B) handling unvaccinated workers exposed to a known and unknown source-person; C) managing vaccinated workers and unknown serological status for hepatitis B and D) cost of the pre-exposure post-vaccination test. Accidents were assessed and the direct cost was calculated using the decision tree model. Results: scenarios where workers did not have protective titles after vaccination or were unaware of the serological status and were exposed to a positive or unknown source-person for hepatitis B. Conclusion: the direct cost of hepatitis B prophylaxis, including confirmation of serological status after vaccination would be more economical for the health system.

Descriptors: Occupational Exposure; Health Personnel; Hepatitis B Vaccines; Hepatitis B Antibodies; Costs and Cost Analysis; Health Care Costs.

\section{How to cite this article}

Souza CL, Salgado TA, Sardeiro TL, Junior HG, Itria A, Tipple AFV. Post-vaccination anti-HBs testing among healthcare workers: More economical than post-exposure management for Hepatitis B. Rev. Latino-Am. Enfermagem. 2020;28:e3278. [Access $f+1]$; Available in: month day year DOI: http://dx.doi.org/10.1590/1518-8345.3534.3278. 


\section{Introduction}

In the world, approximately 257 million individuals live with chronic hepatitis B virus (HBV) infection(1). It is known that the cost of treating this disease is high(2-3).

In Brazil, 233,027 confirmed hepatitis B cases were reported in the period from 1999 to 2018, with detection rates of $6.7 / 100,000$ inhabitants in 2018 , in which $0.3 \%$ of the transmission occurred through the occupational route ${ }^{(4)}$.

Infection by occupational exposure can occur during accidents with biological material among Health Care Workers (HCW), according to studies that show rates of $17.3 \%$ to $58.4 \%$ in Brazil(5-6) and $36,7 \%$ to $78,0 \%$ in other countries ${ }^{(7-9)}$.

In view of the risk of exposure to $\mathrm{HBV}$, the main preventive measure is the vaccination(10). In Brazil, the Unified Health System (SUS - abbreviation in Portuguese) bears the costs of the HBV vaccine within the National Immunization Program, making it available free of charge since $1998^{(11)}$.

The vaccine is safe and effective, ensuring $92 \%$ protection for immunocompetent adults ${ }^{(12)}$. Despite the high protection, it is recommended after vaccination to perform antibodies against surface antigen (anti-HBs) to confirm immunity to the virus ${ }^{(10)}$.

Unlike the HBV vaccine, the anti-HBs test is not routinely available in the public health system after vaccination in Brazil.

In handling the accident with biological material, considering the recommendations of the Centers for Disease Control and Prevention (CDC) ${ }^{(10)}$ and the Ministry of Health in Brazil(13), evaluation of vaccination history and serological status is required for the hepatitis $B$ of $\mathrm{HCW}$ and HBV serological status testing for hepatitis $B$ by the surface antigen (HBsAg) from the known sourceperson at the time of occupational exposure.

After this assessment at the time of the accident, four approaches can be adopted considering the Guidance for Evaluating Health-Care Personnel for Hepatitis B Virus Protection and for Administering Postexposure Management protocol - $\mathrm{CDC}^{(10)}$. Depending on the serological status of the source-person and the victim, the conducts are: No conduct, realizing the vaccine, realizing the vaccine and administering a dose of Hyperimmune Immunoglobulin for Hepatitis B (IGHAHB) and administering two doses of IGHAHB. In the last three aforementioned conducts, the injured worker must perform the anti-HBs test after the vaccine one to two months after the last dose and after four to six months of this immunoglobulin(10).

The management of accidents with biological material among HCW is expensive in several countries, mainly in percutaneous exposures ${ }^{(14-18)}$. Although the performance of the anti-HBs test among these workers is a recommendation of the Ministry of Health and Labor through the Regulatory Norm (NR) $32 / 2005^{(19-20)}$ and the $\mathrm{CDC}^{(10)}$, it is known that a considerable part of the vaccinated $\mathrm{HCW}$ ignore the serological status for the $\mathrm{HBV}^{(5,21-23)}$. Ignoring this status at the time of the accident with a positive source-person requires a high-cost intervention with immunoglobulin, which would turn expensive the post-exposure handling related to the $\mathrm{HBV}^{(15)}$.

In the economic studies, the direct cost involves technology costs for health interventions, including drugs and exams ${ }^{(24-25)}$. The evaluation of costs in the health area is increasingly present in the management of health services; therefore, good quality scientific evidence on costs and health outcomes helps in the decision-making(26).

Since the post-vaccination anti-HBs test is not routinely offered to the worker free of charge by SUS, it was asked what is the lowest cost related to occupational exposure to HBV?

In this sense, the aim of this study was to compare the direct cost, from the perspective of the Unified Health System, of assessing the post-vaccination serological status with post-exposure management for hepatitis B among health care workers exposed to biological material.

\section{Method}

Cross-sectional, descriptive and partial economic evaluation study, focusing on the direct cost of occupational post-exposure management to biological material. The study's population was HCW that suffered accident with exposure to biologic material notified in the database of Aggravated Notification Information System (SINAN-NET), in the municipality of Goiânia, in the period from 2006 to 2016, which corresponds to the beginning of the notifications from the municipality until the last year in which the data were completed and marked a 10-year period of notifications.

The study site is located in the Midwest region of Brazil. According to the Brazilian Institute of Geography and Statistics in 2017, this municipality had 1,466,105 inhabitants ${ }^{(27)}$. There were 3,281 health facilities (public, philanthropic and private networks) and 25,367 HCW working in the health services ${ }^{(28)}$.

To evaluate the direct cost of performing the antiHBs test and the management after exposure to the HBV, the analyzed epidemiological variables were: gender, age, education, professional category, biological material involved, object involved, type of exposure, hepatitis $B$ vaccine of $\mathrm{HCW}$, $\mathrm{HCW}$ anti-HBs test, identification of the source-person and HBsAg of the source-person.

From such data, four scenarios were evaluated, representing the possibilities of intervention considering 
the serological status of the source-person and injured $\mathrm{HCW}(\mathrm{A}, \mathrm{B}, \mathrm{C}, \mathrm{D})$, considering the recommendations of $\mathrm{CDC}^{(10)}$, adopted as a reference for providing greater protection to the workers. In scenario $A$ and $B$, the direct costs for HBV-related post-exposure management were quantified among HCW exposed to biological material from real data, considering the previous vaccination and the result of the worker's anti-HBs test performed at the time of accident (scenario $A$ ) or the nonvaccination of the same (scenario $B$ ). While, in scenario $\mathrm{C}$, the costs of post-exposure management for HBV by simulation were measured, considering epidemiological studies. In this scenario, the HCW did not know the result of the anti-HBs test at the time of occupational exposure, and for the simulation one considered the immunogenicity rate of $92 \%{ }^{(12)}$, the known sourceperson rate of $73 \%^{(21,29-31)}$ and the prevalence of positive HBsAg source-person of $1.0 \%(21,30-31)$.

In scenario $D$, the direct costs of the HBV prevention measure were measured by performing the anti-HBs test 30 days after the last dose of the vaccine, considering that the injured HCW had performed this primary postvaccination test and before the accident with biological material, considering the same immunogenicity rate as scenario $\mathrm{C}$.

This study evaluated the direct cost from SUS perspective, according to the current table of values of the Management System of the Table of Procedures, Medicines and Orthotics, Prostheses and Special Materials (SIGTAP).

For the calculations, we first used the Brazilian currency in Reais ( $R \$$ ) that was converted to the U.S. dollar (US\$) with a value of 1 US $\$=R \$ 3.26$, based on the price of $07 / 15 / 2016$, available on the site of the Central Bank of Brazil.

The values of the technologies (unitary costs) used in this study were US\$ 5.69 the anti-HBs test, US\$ 5.69 the HbsAg test, US\$ 259.75 the IGHAHB of 500 International Units (IU) and US\$ 3.07 medical consultation in worker's health. The costs were calculated considering the number of $\mathrm{HCW}$ multiplied by the value of the test or technology (anti-HBs, HBsAg, IGHAHB and medical consultation) in each scenario.

The cost of the vaccine was not considered in this study for economic analysis, as it was assumed that it would not bring financial impact, since this cost is predicted by the SUS for all HCW(11).

Epidemiological data were processed and analyzed by Statistical Package for the Social Sciences (SPSS ${ }^{\circledR}$ ), version 20.0 using descriptive statistics. The following criteria were considered for data analysis based on the CDC recommendation ${ }^{(10)}$ :
- Vaccinated HCW - those who received the three doses of hepatitis $\mathrm{B}$ vaccine reported by the worker;

- Non-vaccinated HCW - those who did not receive the three doses of the vaccine, vaccine situation ignored and without information;

- HCW with protective titers to HBV - those with antiHBs test $>10 \mathrm{IU} /$ millilitres $(\mathrm{ml})$;

- HCW without protective titers to HBV - those with anti-HBs test;

- Unknown source-person - those with inconclusive HBsAg test, not performed, ignored and without information, whose management, recommended by the $\mathrm{CDC}^{(10)}$, is the same for those with positive HBsAg;

- Vaccinated HCW and with unknown anti-HBs test those with inconclusive test, not performed, ignored or without information.

- For the cost analysis of IGHAHB, the prescription of 500 IU was considered as the standard dose, since it is the minimum dosage prescribed for adults(32).

The economic analysis used was the decision tree model; this graphic representation begins from the left with a decision node, which is divided into branches that propose to evaluate comparatively. In each branch, the probabilities of events must be described until the final event. Therefore, a series of probability nodes appear in each branch. At the end of these branches, the outcomes are presented as terminal node, indicating the final impacts of each branch with their respective costs associated with each analyzed event ${ }^{(33-34)}$.

The approach used for the analysis was macrocosting or some top-down method, which allows for a cost analysis of secondary data retrospectively(24).

A study approved in the research ethics committee of Clinical Hospital, Federal University of Goiás, under protocol no. $41425 / 2013$.

\section{Results}

There were recorded 7,265 accidents with biological material among HCW in the city of Goiânia from 2006 to 2016 , aged from 21 - 30 years old (39.3\%), with a predominance of females $(80.5 \%)$ and with high school education (43.0\%). The most exposed team was nursing $(55.2 \%)$, followed by the physician (10.2\%).

Regarding the profile of accidents with biological material, percutaneous exposures predominated $(72.4 \%)$ in the presence of blood $(74.4 \%)$, and the most involved objects were needles with and without lumen (62.1\%).

For post-exposure management of biological material it is necessary to know the vaccination history against hepatitis $B$ and serological status (anti-HBs test) 
of the HCW at the time of the accident and the serological status (HBsAg) of the source-person when known. Regarding the vaccination history against hepatitis $B$, it was recorded in the accident notification form that $6,184(85.1 \%)$ workers had received all three doses of the vaccine, $542(7.5 \%)$ were not vaccinated or did not complete the vaccination schedule and in 539 (7.4\%) cases there was no record of this information.

Regarding serological status to HBV, of the 6,184 vaccinated $\mathrm{HCW}$ (Figure 1), 2,756 (44.6\%) performed the anti-HBs test, of which 1,758 (63.8\%) had protective titers at the time of the accident and 998 $(36.2 \%)$ didn't have it. Of the 3,428 workers who did not undergo the anti-HBs test (Figure 3 ), when considering the $92 \%$ immunogenicity rate for hepatitis B vaccine, it is assumed that 3,154 (92\%) had protective titles for the virus and $274(8 \%)$ would not possess.

Regarding the serological status ( $\mathrm{HBsAg}$ ) of the source-person, a prevalence of positive HBsAg was observed among known source people of 1.8\% (95\% CI: 1.0 - 3.2). Among vaccinated HCW against hepatitis $B$ and with anti-HBs $<10 \mathrm{IUV} \mathrm{ml}$, the prevalence of positive HBsAg with known source-person was $0.9 \%$ (95\% CI: $0.3-2.0$ ) and among unvaccinated $\mathrm{HCW}$, the prevalence of positive HBsAg with known source-person was $5.1 \%$ (95\% CI: $2.3-9.8$ ).

The costs were presented in the branches of the "decision tree" model, with the costs of post-exposure management described in scenarios A (Figure 1), B (Figure 2) and C (Figure 3 ) and the cost of postvaccination prevention primary in scenario D (Figure 4).

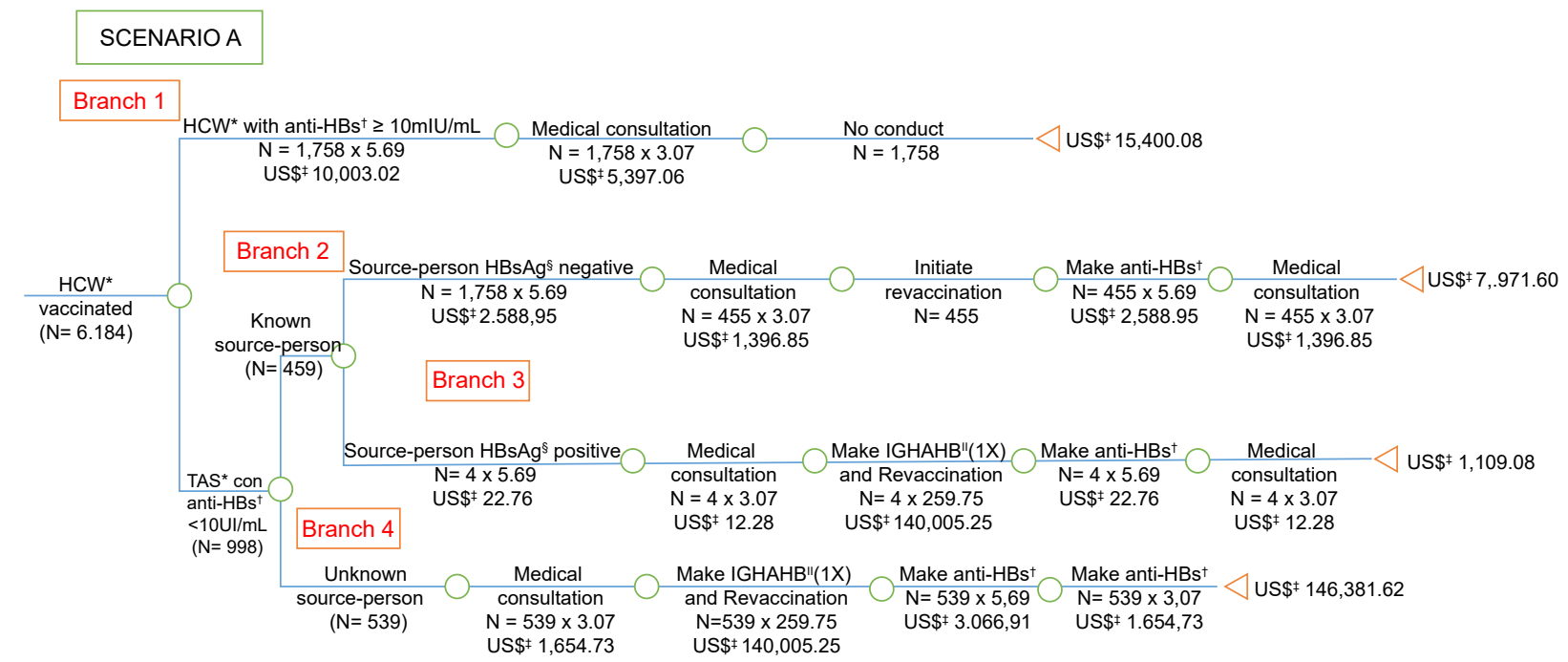

${ }^{*} \mathrm{HCW}=$ Health Care Worker; ${ }^{+}$anti-HBs $=$Antibody against hepatitis $\mathrm{B}$ virus surface antigen; ${ }^{*}$ US $\$=$ Conversion rate: 1 US $\$=3,26$ in $07 / 15 / 2016$; ${ }^{\S} \mathrm{HBSAg}=$ Surface antigen for hepatitis B; "IGHAHB = Immunoglobulin hyper-immune for hepatitis B

Figure 1 - Economic analysis of post-exposure management for hepatitis B among health care workers, victims of accidents with biological material, vaccinated against hepatitis B ( 3 doses) and anti-HBs at the time of the accident, considering the recommendations of the Centers for Disease Control and Prevention. Goiânia, GO, Brazil, 2006-2016

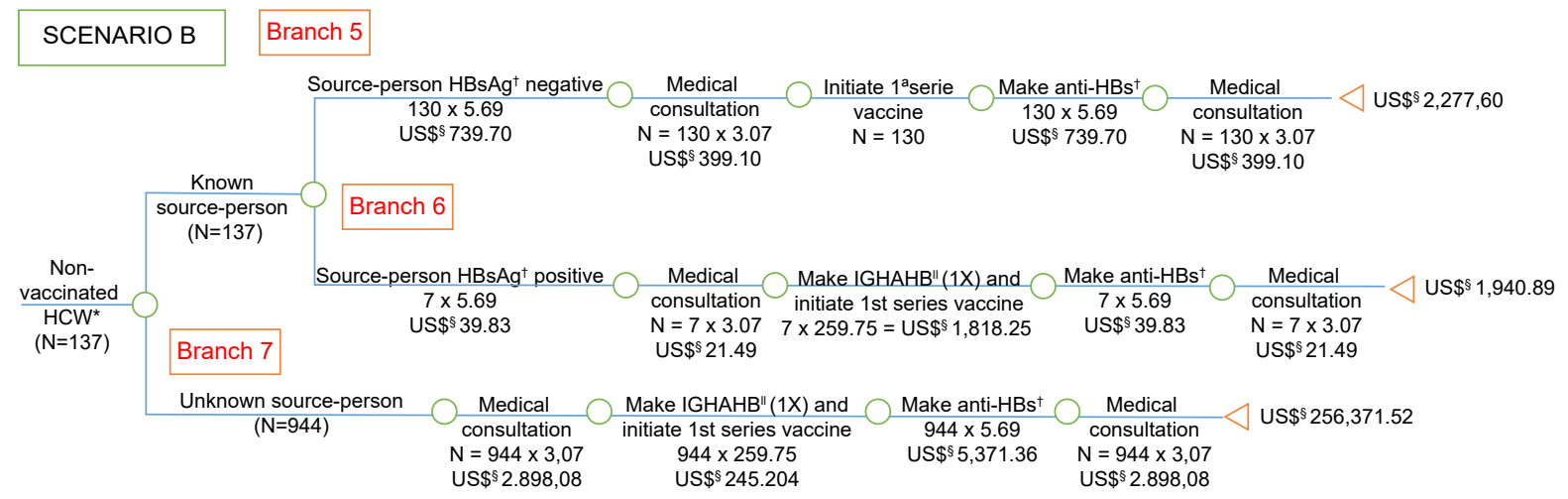

${ }^{*} \mathrm{HCW}=$ Health Care Worker; ${ }^{+} \mathrm{HBsAg}=$ Surface antigen for hepatitis $\mathrm{B} ;{ }^{\ddagger}$ anti-HBs $=$ Antibody against hepatitis B virus surface antigen; ${ }^{\text {s }} \mathrm{SS} \$=\mathrm{Conversion}$ rate: 1 US $\$=3.26$ in 07/15/2016; "IGHAHB = Hyperimmune immunoglobulin for hepatitis B

Figure 2 - Economic analysis of post-exposure management for hepatitis B among health care workers, victims of accidents with biological material, not vaccinated against hepatitis B (3 doses), exposed to known and unknown source people, exposed to known and unknown source people, considering the recommendations of the Centers for Disease Control and Prevention. Goiânia, GO, Brazil, 2006-2016 
\begin{tabular}{l|l|l} 
SCENARIO C & Branch 8
\end{tabular}

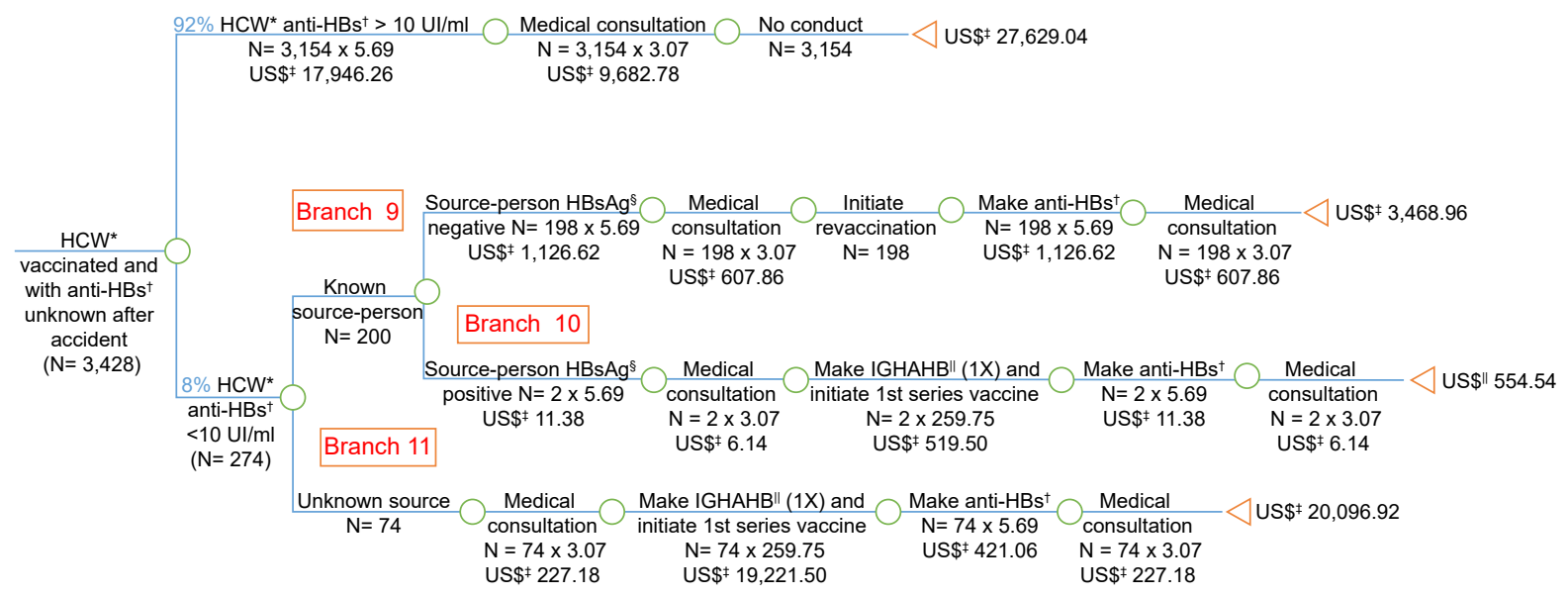

${ }^{*} \mathrm{HCW}=$ Health Care Worker; ${ }^{+}$anti-HBs $=$Antibody against hepatitis B virus surface antigen; ${ }^{*}$ US $\$=$ Conversion rate: 1 US $\$=3.26$ in $07 / 15 / 2016$; § $\mathrm{HBsAg}=$ Surface antigen for hepatitis B; "IGHAHB = Hyperimmune immunoglobulin for hepatitis B

Figure 3 - Economic analysis of the simulation of occupational post-exposure management of biological material for hepatitis B among health care workers, victims of accidents with biological material, vaccinated and with unknown anti-HBs test after the accident with biological material, considering the recommendations of the Centers for Disease Control and Prevention. Goiânia, GO, Brazil, 2006-2016

SCENARIO D

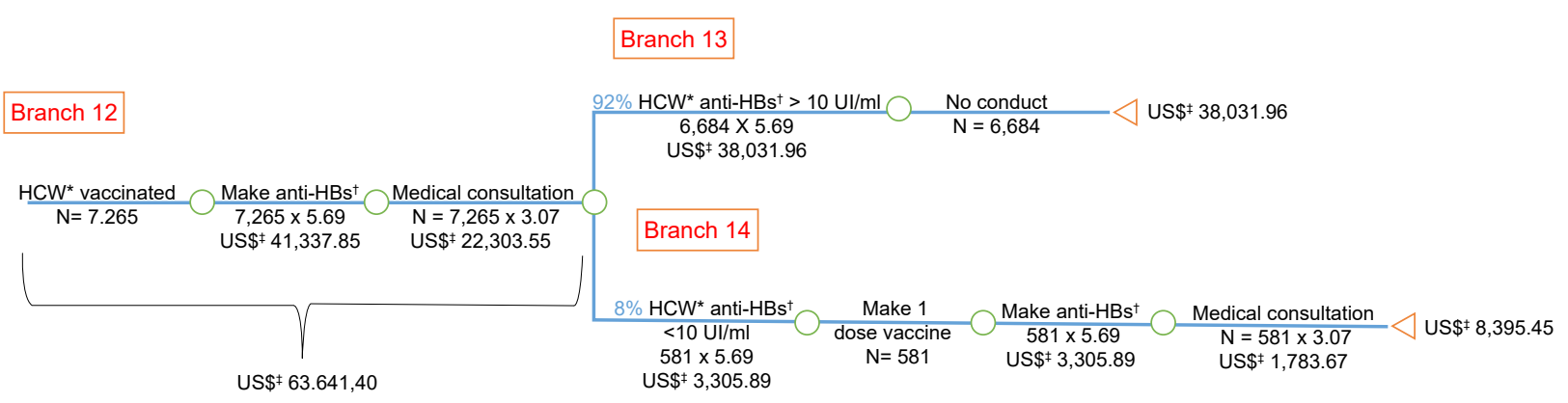

${ }^{*} \mathrm{HCW}=$ Health Care Worker; ${ }^{+}$anti-HBs $=$Antibody against hepatitis B virus surface antigen; ${ }^{*} \mathrm{US} \$=$ Conversion rate: 1 US\$ $=3.26$ in $07 / 15 / 2016$

Figure 4 - Economic analysis of the evaluation of serological status after primary vaccination for hepatitis B among health care workers, victims of accidents with biological material, considering the recommendations of the Centers for Disease Control and Prevention. Goiânia, GO, Brazil, 2006-2016

The cost of prevention measures before the accident with biological material and the management after vaccination history and serological status for the HBV exposure to HBV among the injured HCW in relation to of the worker and the source-person is described in Table 1.

Table 1 - Economic analysis of prevention measures and post-exposure management among health care workers, victims of accidents with biological material in the municipality of Goiânia. Goiânia, GO, Brazil, 2006-2016

\begin{tabular}{|c|c|c|}
\hline \multirow{2}{*}{$\begin{array}{l}\text { Handling situation } \\
\text { post-exposure }(n)\end{array}$} & \multicolumn{2}{|c|}{ Dollar Costs (US\$*) } \\
\hline & Total & Per capita \\
\hline \multicolumn{3}{|l|}{ Vaccinated } \\
\hline $\mathrm{HCW}^{\dagger}$ with anti-HBs ${ }^{\ddagger}$ positive $(1,758)$ & $15,400.08$ & 8.76 \\
\hline $\mathrm{HCW}^{\dagger}$ with anti-HBs ${ }^{\ddagger}$ negative with source-person $\mathrm{HBsAg}^{\S}$ negative (455) & $7,971.60$ & 17.52 \\
\hline $\mathrm{HCW}^{\dagger}$ with anti-HBs${ }^{\ddagger}$ negative with source-person $\mathrm{HBsAg}^{\S}$ positive (4) & $1,109.08$ & 277.27 \\
\hline $\mathrm{HCW}^{\dagger}$ with anti-HBs ${ }^{\ddagger}$ negative with unknown source-person (539) & $146,381.62$ & 271.58 \\
\hline
\end{tabular}




\begin{tabular}{|c|c|c|}
\hline \multirow{2}{*}{$\begin{array}{l}\text { Handling situation } \\
\text { post-exposure (n) }\end{array}$} & \multicolumn{2}{|c|}{ Dollar Costs (US\$*) } \\
\hline & Total & Per capita \\
\hline \multicolumn{3}{|l|}{ Non-vaccinated } \\
\hline $\mathrm{HCW}^{+}$with source-person $\mathrm{HBsAg}^{\S}$ negative $(130)$ & $2,277.60$ & 17.52 \\
\hline $\mathrm{HCW}^{+}$with source-person $\mathrm{HBsAg}{ }^{\S}$ positive $(7)$ & $1,940.89$ & 272.13 \\
\hline $\mathrm{HCW}^{+}$with unknown source-person (944) & $256,371.52$ & 271.58 \\
\hline \multicolumn{3}{|l|}{$\mathrm{HCW}^{\dagger}$ vaccinated with anti-HBs test $\mathrm{t}^{\ddagger}$ unknown after the accident } \\
\hline $\mathrm{HCW}^{\dagger}$ with anti-HBs ${ }^{\ddagger}$ positive $(3.154)$ & $27,629.04$ & 8.76 \\
\hline $\mathrm{HCW}^{\dagger}$ with anti-HBs ${ }^{\ddagger}$ negative with source-person $\mathrm{HBsAg}^{\S}$ negative (198) & $5,203.44$ & 26.28 \\
\hline $\mathrm{HCW}^{+}$with anti-HBs ${ }^{\ddagger}$ negative with source-person $\mathrm{HBsAg}^{\S}$ positive (2) & 554.54 & 277.27 \\
\hline $\mathrm{HCW}^{+}$with anti-HBs $\ddagger$ negative with unknown source-person (74) & $20,096.92$ & 271.58 \\
\hline Vaccinated with anti-HBs ${ }^{\ddagger}$ primary post-vaccination $(7,265)$ & $63,641.40$ & 8.76 \\
\hline
\end{tabular}

*US\$ = Conversion rate: 1 US $\$=3.26$ in $07 / 15 / 2016 ;{ }^{+} \mathrm{HCW}=$ Health Care Worker; ${ }^{\ddagger}$ anti-HBs $=$ Antibody against hepatitis $\mathrm{B}$ virus surface antigen;

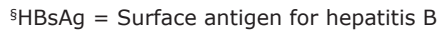

\section{Discussion}

The predominance, in this study, of accidents with biological material among female $\mathrm{HCW}$, agrees with other Brazilian studies ${ }^{(5-6,21,35-36)}$ and of other countries ${ }^{(9,37-38)}$. Regarding age group, there was verified, in accordance with other researches(39-40), higher prevalence of young adult workers.

As for the health team, the nursing team corresponds to the largest number of professionals in the health services, being the one who first assists the patient and is present from the admission to the discharge ${ }^{(41)}$, is responsible for numerous procedures ${ }^{(41)}$, which is why the higher incidence of accidents is inferred.

As identified in other researches ${ }^{(21,29,37,42-43)}$, in this study, it was identified that the most frequent object in accidents was the needle with and without lumen, therefore exposure to sharp objects prevailed, followed by exposure to mucous membranes. Exposures involving blood were the most numerous, as found in studies in the state of Goiás ${ }^{(36,44)}$, in other Brazilian states $^{(6,21,42)}$ and in other countries ${ }^{(7,29,37)}$. Together, the data characterizes a population that should be the target of accident prevention campaigns and the need for investments in professional training to reduce biological occupational risk.

An essential preventive measure against HBV infection is vaccination, and the HCW needs to have it documented(10,13). Studies show vaccination frequencies against hepatitis B (three doses) of 73,5\% to $97,5 \%$ among $\mathrm{HCW}$, victims of biological material accident $(21,29,35)$, the vaccination rate of this study is in this range $(85.1 \%)$, showing that policies to encourage and monitor the immunization of workers are, still, fundamental and deserve the attention of the managers.

Following vaccination against hepatitis $B$, the performance of the anti-HBs test is essential for the safety of workers, as it will demonstrate the immunological status for the $\mathrm{HBV}^{(10,13)}$. In Brazil, the rate of carrying out this test after primary vaccination in this group varied between $30.4 \%{ }^{(45)} ; 27.9 \%{ }^{(23)}$ and $4.1 \%{ }^{(36)}$.

The anti-HBs test is not available in all hospitals for emergencies, as in the case of accidents with biological material(46). At the reference units for this type of care, at the study site, blood samples are collected from the injured HCW for the performance of various serologies, including anti-HBs, and the results are delivered after 30 days. Despite the recommendation to perform this test in post-exposure management ${ }^{(10,13)}$, its performance in this study was low (44.6\%), as shown in other studies in Brazil, in which the rate of anti-HBs testing among HCW exposed to biological material, in the accident time, ranged from $14.6 \%$ to $52.8 \%(21-23,30-31,47)$.

Regarding the serologic status of the source-person for HBsAg positive, a rate of $1.8 \%$ ( $95 \%$ CI $1.0-3.2$ ) was observed in this study. Rate of $0.5 \%$ to $1.4 \%^{(21,30-31)}$ were identified in the literature.

In Scenario A (Figure 1), it was observed that four HCW with anti-HBs $<10 \mathrm{IU} / \mathrm{ml}$ were exposed to HBsAg positive source-person; therefore the conduct recommended by the $\mathrm{CDC}^{(10)}$ is the administration of one dose of IGHAHB and one dose of the vaccine, simultaneously and as soon as possible, as the efficacy of IGHAHB, when administered after seven days of exposure, is unknown ${ }^{(10)}$. In this case, the direct cost of this group was US $\$ 1,109.08$, corresponding to US \$277.27 per worker. The direct cost could have been avoided with the second vaccination schedule followed by the anti-HBs test, as probably the number of HCW with anti-HBs <10 IU/ mL would be lower, since the worker can respond to a second schedule ${ }^{(10)}$.

The health protection of the HBP-related HCW is very explicit in Collegiate Board Resolution No. 11, 
which provides for the requirements of good operating practices for dialysis services, as it prohibits workers without protective titles to HBV, to carry out assistance during the session of hemodialysis and, in the processing of dialyzers and arterial and venous lines of patients with positive serology for hepatitis $\mathrm{B}^{(48)}$. However, this regulation does not apply to other areas of care, which also offer risk of contact with blood from HBV-positive patients; then it is considered necessary to encourage the performance of anti-HBs testing among all HCW.

Considering the prevention for $\mathrm{HBV}$, it is interesting to note that NR 32/2005 ensures that all HCW should be provided with the hepatitis $B$ vaccine, free of charge, with the employer must keep supporting document and keep it available for labor inspection. However, when it comes to anti-HBs testing, the standard is not so clear. Declares that the employer must monitor the effectiveness whenever recommended by the Ministry of Health and, when necessary, provide the vaccine booster ${ }^{(20)}$.

Although the vaccine is provided free by SUS, in this study, it was observed that there are still HCW without vaccination, according to scenario B (Figure 2). Therefore, it would be important for managers to provide effective strategies to ensure vaccine completion for workers prior to admission to the health service ${ }^{(49)}$.

In scenario B (Figure 2), HCW not vaccinated against hepatitis $B$ were analyzed. These workers who had an accident with a positive HBsAg source-person had a high cost to the health system, as well as those who had an unknown source-person accident. However, scenario D (Figure 4) in which the test was performed before exposure was the one with the lowest cost when compared to the other scenarios.

Consequently, when comparing the per capita cost of scenario A (Figure 1 ) in which the $\mathrm{HCW}$ vaccinated with the anti-HBs test $<10 \mathrm{IU} / \mathrm{mL}$ was exposed to $\mathrm{HBsAg}$ positive source-person with the scenario $D$ (Figure 4) of the vaccinated worker and with the anti-HBs test $>10 \mathrm{IU} / \mathrm{mL}$ after hepatitis $B$ vaccine before the accident with biological material, it was noted that the first cost was about 32 times more expensive for SUS (Table 1). Thus, the opportunity to allocate resources to other programs, including those aimed at the health of the own workers, is lost ${ }^{(20)}$.

When comparing the per capita cost of the HCW vaccinated with the anti-HBs test $<10 \mathrm{IU} / \mathrm{ml}$ (scenario A - Figure 1) who had an accident with an unknown source-person with a worker vaccinated with anti-HBs after primary vaccination (scenario D - Figure 4), the cost was approximately 31 times higher. As well, when checking the per capita cost of the HCW vaccinated with the anti-HBs test $<10 \mathrm{IU} \vee \mathrm{ml}$ (scenario A - Figure 1) exposed to HBsAg-negative source-person with the worker vaccinated with anti-HBs primary vaccination (scenario D - Figure 4), the cost was in about twice as expensive for SUS.

In cases of post-exposure management of unvaccinated HCW (scenario B - Figure 2), the per capita costs were elevated when compared also to the worker vaccinated with anti-HBs after primary vaccination (scenario D - Figure 4), being 32 times more expensive for SUS when the SAD was exposed to HBsAg-positive source-person and 31 times higher when the personsource was unknown.

When comparing the per capita cost of vaccinated $\mathrm{HCW}$ and with anti-HBs $<10 \mathrm{IU} / \mathrm{ml}$ exposed to HBsAgpositive source-person (scenario C - Figure 3) with the cost of the worker vaccinated with anti-HBs after primary vaccination (scenario D - Figure 4 ), the cost was around 32 times higher for SUS. Still in the scenario $C$ (Figure 3), when comparing the per capita cost of HCW with negative anti-HBs exposed to unknown sourceperson with the worker's cost vaccinated with anti-HBs after primary vaccination (scenario D - Figure 4), the cost was 31 times more costly for SUS.

A Brazilian study showed that HBV infection has high costs for the health system, with an average annual cost per patient of $U \$ 117$ to 11,488 depending on medication $^{(2)}$, without mentioning the costs of carrying out tests for the clinical and laboratory monitoring of the injured worker. The cost for treating hepatitis $B$ is also high in other countries(50-51).

Therefore, when the health system pays for preventable disease treatments, the opportunity to invest in effective prevention and promotion measures is lost ${ }^{(52)}$. Such analysis can be performed through the opportunity cost, which represents the cost of losing the opportunity to apply financial resources in other health technologies or programs that have a positive impact on public health(53).

This study showed that the allocation of SUS resources to preventive measures, including the provision and monitoring of anti-HBs tests to all HCW, is more economical than post-exposure management and these data can support public policies on worker health, ensuring greater security at a lower cost. Some gaps found in the SINAN-NET database were its limitation.

\section{Conclusion}

The direct cost of post-exposure prophylaxis for SUS was about 30 times more expensive than the costs of post-vaccination testing in those accidents in which the source-person was positive or unknown and the professional had unknown anti-HBs.

Scenarios A (branch three and four), scenario B (branch six and seven) and scenario $C$ (branch 10 and 11) 
for post-exposure management to HBV when compared to scenario $D$, which represents the primary vaccination followed by confirmation of immunity confirmed by the anti-HBs test, showed greater per capita cost impact.

Health managers can rely on the findings of this study for the implementation of the routine of carrying out the post-vaccination anti-HBs test, ensuring greater protection to the health of the worker with a reduction in the costs of post-exposure management related to HBV, optimizing scarce public resources in our country.

\section{References}

1. World Health Organization. Global hepatitis report 2017. [Internet]. Geneva: World Health Organization; 2017. [cited April 13, 2018]. Available from: https:// apps.who.int/iris/bitstream/handle/10665/255016/978 9241565455eng. pdf; jsessionid =0DA6245F73DE62CA74 AFDA377EDEAAC9? sequence $=1$

2. Wiens A, Lenzi L, Venson R, Pedroso ML, Correr CJ, Pontarolo R. Economic evaluation of treatments for chronic hepatitis B. Braz J Infect Dis. 2013;17(4): 418-26. doi: https://doi.org/10.1016/j.bjid.2012.12.005 3. Zhang S, Ma Q, Liang S, Xiao H, Zhuang G, Zou Y, et al. Annual economic burden of hepatitis $B$ virus-related diseases among hospitalized patients in twelve cities in China. J Viral Hepat. 2016;23(3):202-10. doi: https:// doi.org/10.1111/jvh.12482

4. Ministério da Saúde (BR). Boletim epidemiológico de hepatites virais. [Internet]. 2019. [Acesso 20 out 2019]. Disponível em: http://www.aids.gov.br/pt-br/pub/2019/ boletim-epidemiologico-de-hepatites-virais-2019

5. Carvalho DC, Rocha JC, Gimenes MCA, Santos EC, Valim MD. Work incidents with biological material in the nursing team of a hospital in Mid-Western Brazil. Esc Anna Nery. [Internet]. 2018 [cited Apr 20, 2018];22(1): 1-8. Available from: http://www.scielo.br/pdf/ean/ v22n1/1414-8145-ean-2177-9465-EAN-2017-0140.pdf 6. Negrinho NBS, Malaguti-Toffano SE, Reis RK, Pereira FMV, Gir E. Factors associated with occupational exposure to biological material among nursing professionals. Rev Bras Enferm. [Internet]. 2017 [cited Jun 20, 2018];70(1): 126-31. Available from: http://www.scielo.br/pdf/reben/ v70n1/en_0034-7167-reben-70-01-0133.pdf

7. Nouetchognou JS, Ateudjieu J, Jemea B, Mbanya D. Accidental exposures to blood and body fluids among health care workers in a Referral Hospital of Cameroon. BMC Res Notes. [Internet]. 2016 [cited Jul 10, 2018];9(94):16. Available from: https://www.ncbi.nlm.nih.gov/pmc/ articles/PMC4753641/pdf/13104_2016_Article_1923.pdf

8. Garus-Pakowska A, Górajski M, Szatko F. Awareness of the risk of exposure to infectious material and the behaviors of Polish paramedics with respect to the hazards from blood-borne pathogens - a nationwide study. Int J Environ Res Public Health. [Internet]. 2017 [cited Ago 10, 2018];14(843):1-9. doi: 10.3390/ijerph14080843

9. Matsubara C, Sakisaka K, Sychareun V, Phensavanh A, Ali M. Prevalence and risk factors of needle stick and sharp injury among tertiary hospital workers, Vientiane, Lao PDR. Occup Health. [Internet]. 2017 [cited Nov 20, 2018];59(6):581-5. Available from: https://www.ncbi. nlm.nih.gov/pmc/articles/PMC5721280/pdf/1348-958559-581.pdf

10. Centers for Disease Control and Prevention. CDC Guidance for evaluating health-care personnel for hepatitis B virus protection and for administering postexposure management. MMWR Recommendations and reports: Morbidity and mortality weekly report Recommendations and reports. [Internet]. 2013 [cited Nov 20, 2018];62(RR):1-22. Available from: https:// www.cdc.gov/mmwr/preview/mmwrhtml/rr6210a1.htm 11. Ministério da Saúde (BR). Programa Nacional de Imunizações (PNI): 40 anos. [Internet]. 2013 [Acesso 20 mar 2018]. Disponível em: http://bvsms.saude.gov.br/bvs/ publicacoes/programa_nacional_imunizacoes_pni40.pdf 12. Averhoff F, Mahoney F, Coleman P, Schatz G, HurwitzE, Margolis $\mathrm{H}$. Immunogenicity of hepatitis $B$ Vaccines. Implications for persons at occupational risk of hepatitis $B$ virus infection. Am J Prev Med. [Internet]. 1998 [cited Nov 20, 2018];15(1):1-8. doi: https://doi.org/10.1016/ S0749-3797(98)00003-8

13. Ministério da Saúde (BR). Protocolo clínico e diretrizes terapêuticas para profilaxia pós-exposição (pep) de risco à infecção pelo HIV, IST, e hepatites virais. [Internet]. 2018 [Acesso 20 nov 2018]. Disponível em: http://www.aids.gov.br/pt-br/pub/2015/protocoloclinico-e-diretrizes-terapeuticas-para-profilaxia-posexposicao-pep-de-risco

14. O'Malley EM, Scott RD 2nd, Gayle J, Dekutoski J, Foltzer M, Lundstrom TS, et al. Costs of management of occupational exposures to blood and body fluids. Infect Control Hosp Epidemiol. 2007;28(7):774-82. doi: https://doi.org/10.1086/518729

15. Oh HS, Yoon Chang SW, Choi JS, Park ES, Jin HY. Costs of postexposure management of occupational sharps injuries in health care workers in the Republic of Korea. Am J Infect Control. 2013;41(1):61-5. doi: https://doi.org/10.1016/j.ajic.2012.01.030

16. Lee JM, Botteman MF, Xanthakos N, Nicklasson L. Needlestick injuries in the United States. Epidemiologic, economic, and quality of life issues. AAOHN J. [Internet]. 2005 [cited Nov 20, 2018];53(3):117-33. Available from: https://www.ncbi.nlm.nih.gov/pubmed/15789967

17. Leigh JP, Gillen M, Franks P, Sutherland S, Nguyen $\mathrm{HH}$, Steenland $\mathrm{K}$, et al. Costs of needlestick injuries and subsequent hepatitis and HIV infection. Curr Med 
Res Opin. 2007;23(9):2093-105. doi: https://doi. org/10.1185/030079907X219517

18. Mannocci A, De Carli G, Di Bari V, Saulle R, Unim $B$, Nicolotti $N$, et al. How much do needlestick injuries cost? A systematic review of the economic evaluations of needlestick and sharps injuries among healthcare personnel. Infect Control Hosp Epidemiol. 2016;37(6):635-46. doi: https://doi.org/10.1017/ice.2016.48

19. Ministério da Saúde (BR). Recomendações para terapia antirretroviral em adultos infectados pelo HIV- 2008. Suplemento III - Tratamento e prevenção. [Internet]. 2010. [Acesso 10 jan 2017]. Disponível em: http://www.aids. gov.br/sites/default/files/pub/2016/59204/suplemento_ consenso_adulto_01_24_01_2011_web_pdf_13627.pdf 20. Ministério do Trabalho e Emprego (BR). Portaria n. 0 485, de 11 de novembro de 2005. NR 32- Segurança e Saúde no Trabalho em Serviços de Saúde. [Internet]. 2005 [Acesso 20 jan 2018]. Disponível em: https://www20. anvisa.gov.br/segurancadopaciente/index.php/legislacao/ item/portaria-n-485-de-11-de-novembro-de-2005

21. Arantes MC, Haddad MCFL, Marcon SS, Rossaneis MA, Pissinati PSC, Oliveira SA. Occupational accidents with biological material among healthcare workers. Cogitare Enferm [Internet]. 2017 Jan-Mar [cited Jan 20, 2018];22(1):1-8. Available from: https://revistas.ufpr. br/cogitare/article/view/46508/pdf_en

22. Garbin CAS, Wakayama B, Dias IA, Bertocello LM, Garbin AJI. Hepatitis B and occupational exposure in the dental setting. The valuation of the knowledge and professionals attitudes. J Health Sci. [Internet]. 2017 [cited Ago 18, 2018];19(2):209-13. Available from: http://pgsskroton.com.br/seer/index.php/JHealthSci/ article/view/5053/3683

23. Cavalcante MLR, Viana LS, Vasconcelos JO, Linhares MSC. Perfil dos acidentes de trabalho com exposição a material biológico no município de Sobral-Ceará, 2007 a 2014. Essentia. [Internet]. 2016 [Acesso 8 set 2018];17(2):1-22. Disponível em: http://www.uvanet. br/essentia/index.php/revistaessentia/article/view/75/84 24. Silva EN, Silva MT, Pereira MG. Identifying, measuring and valuing health costs. Epidemiol Serv Saúde. [Internet]. 2016 Abr-Jun [cited Feb 20, 2018];25(2): 437-9. Available from: http://scielo.iec.gov.br/pdf/ess/ v25n2/2237-9622-ess-25-02-00437.pdf.

25. Ministério da Saúde (BR). Secretaria de Ciência, Tecnologia e Insumos Estratégicos. Departamento de Ciência e Tecnologia. Diretrizes metodológicas: diretriz de avaliação econômica. [Internet]. 2014. [Acesso 20 jan 2018]. Disponível em: http://bvsms.saude.gov. br/bvs/publicacoes/diretrizes_metodologicas_diretriz_ avaliacao_economica.pdf

26. Silva EN, Silva MT, Pereira MG. Health economic evaluation studies: definition and applicability to health systems and services. Epidemiol Serv Saúde. [Internet]. 2016 Jan/Mar [cited Fev 20, 2018];25:(1):205-7. Available from: http://scielo.iec.gov.br/pdf/ess/v25n1/v25n1a23.pdf 27. Instituto Brasileiro de Geografia Estatística. Estimativas de população. Estimativas da população residente no Brasil e unidades da Federação com data de referência em 10 de julho de 2017. [Internet] 2017. [Acesso 10 jan 2020]. Disponível em: ftp://ftp.ibge.gov. br/Estimativas_de_Populacao/Estimativas_2017

28. Ministério da Saúde (BR). Cadastro Nacional de Estabelecimentos de Saúde. CNESnet - Secretaria de Atenção à Saúde DATASUS. Estabelecimentos cadastrados no Estado Goiás. [Internet] 2017. [Acesso 10 jan 2020]. Disponível em: http://cnes.datasus.gov. br/pages/estabelecimentos/consulta.jsp

29. Goel V, Kumar D, Lingaiah R, Singh S. Occurrence of needlestick and injuries among health-care workers of a tertiary care teaching hospital in North India. J Lab Physicians. [Internet]. 2017 Jan-Mar [cited Jun 2, 2018];9(1):20-5. Available from: http://www.jlponline. org/temp/JLabPhysicians9120-4059725_111637.pdf

30. Sistema de Vigilância de Acidentes de Trabalho com material biológico em serviços de saúde brasileiros (BR). Relatório PSBio. $1^{\text {a }}$ fase: 2002 a 2004, 2a fase: 2005 a 2015. [Internet]. Rio de Janeiro: PSBio; 2015. [Acesso 2 jun 2018];1-21. Disponível em: https://www. riscobiologico.org/psbio/psbio_201505.pdf

31. Santos SS, Costa NA, Mascarenhas MDM. Caracterização das exposições ocupacionais a material biológico entre trabalhadores de hospitais no Município de Teresina, Estado do Piauí, Brasil, 2007 a 2011. Epidemiol Serv Saúde. [Internet]. 2013 Jan-Mar [Acesso 12 dez 2018];22(1):165-70. Disponível em: http:// scielo.iec.gov.br/pdf/ess/v22n1/v22n1a17.pdf

32. Ministério da Saúde (BR). Secretaria de Vigilância em Saúde. Departamento de Vigilância das Doenças Transmissíveis. Manual dos Centros de Referência para imunobiológicos especiais. [Internet]. 2014. [Acesso 12 dez 2018]. Disponível em http://portalarquivos. saude.gov.br/images/pdf/2014/dezembro/09/ manual-cries-9dez14-web.pdf

33. Petrou S, Gray A. Economic evaluation using decision analytical modelling: design, conduct, analysis, and reporting. BMJ. 2011;342:d1766. doi: https://doi. org/10.1136/bmj.d1766

34. Soárez PC, Soares MO, Novaes HMD. Decision modeling for economic evaluation of health technologies. Ciênc Saúde Coletiva. [Internet]. 2014 [cited Jun 2, 2017];19 (10):4209-22. Available from: http://www. scielo.br/pdf/csc/v19n10/1413-8123-csc-19-10-4209.pdf 35. Cordeiro TMSC, Carneiro JN Neto, Cardoso MCB, Mattos AIS, Santos KOB, Araújo TM. Occupational accidents with exposure to biological material: 
description of cases in Bahia. J Epidemiol Infect Control. [Internet]. 2016 [cited Dec 12, 2018];6(2):1-7. doi: http://dx.doi.org/10.17058/reci.v6i2.6218

36. Barros DX, Tipple AFV, Lima LKOL, Souza ACS, Neves ZCP, Salgado TA. Analysis of 10 years of accidents with biological material among the nursing staff. Rev Eletr Enferm. 2016;18:e1157. doi: http://dx.doi. org/10.5216/ree.v18.35493

37. Samargandy SA, Bukhari LM, Samargandy SA, Bahlas RS, Aldigs EK, Alawi MA, et al. Epidemiology and clinical consequences of occupational exposure to blood and other body fluids in a university hospital in Saudi Arabia. Saudi Med J. [Internet]. 2016 [cited Nov 02, 2018];37(7):783-90. Available from: https:// www.ncbi.nlm.nih.gov/pmc/articles/PMC5018644/pdf/ SaudiMed]-37-783.pdf

38. Kocur E, Śliwa-Rak BO, Grosicki S. Analysis of occupational exposures to blood registered in the General Hospital in Zabrze in the years 2006-2015. Przegl Epidemiol. [Internet]. 2016 [cited Fev 12, 2018];70(4):603-15. Available from: http://www. przeglepidemiol.pzh.gov.pl/pobierz-artykul?id=2120.

39. Silva AR, Ferreira OC Jr, Sá RSA, Correia AL Jr, Silva SGC, Carvalho MAL Netto, et al. HBV and HCV serological markers in health professionals and users of the Brazilian Unified Health System network in the city of Resende, Rio de Janeiro, Brazil. J Bras Patol Med Lab. [Internet]. 2017 [cited Jan 22, 2018];53(2): 92-9. Available from: http://www.scielo.br/pdf/jbpml/ v53n2/1676-2444-jbpml-53-02-0092.pdf

40. Almeida MCM, Canini SRMS, Reis RK, Toffano SEM, Pereira FMV, Gir E. Clinical treatment adherence of health care workers and students exposed to potentially infectious biological material. Rev Esc Enferm USP. [Internet]. 2015 [cited Jun 22, 2018];49(2):259-64. Available from: http:// www.scielo.br/scielo.php?script=sci_arttext\&pid=S008062342015000200259\&Ing=en\&nrm=iso\&tlng=en

41. Conselho Federal de Enfermagem (BR), FIOCRUZ. Perfil da enfermagem no Brasil. [Internet]. Goiás: COFEN; 2015. [Acesso 22 jun 2018]. Disponível em: http://www. cofen.gov.br/perfilenfermagem/pdfs/relatoriofinal.pdf

42. Santos EP Junior, Batista RRAM, Almeida ATF, Abreu RAA. Acidente de trabalho com material perfurocortante envolvendo profissionais e estudantes da área da saúde em hospital de referência. Rev Bras Med Trab. [Internet]. 2015 [Acesso 22 nov 2018];13(2):69-75. Disponível em: http://www.anamt. org.br/site/upload_arquivos/rbmt_volume_13_n\%C2\% BA_2_29320161552145795186.pdf

43. Bush C, Schmid K, Rupp ME, Watanabe-Galloway S, Wolford B, Sandkovsky U. Bloodborne pathogen exposures: difference in reporting rates and individual predictors among health care personnel. Am J
Infect Control. 2017;45(4):372-6. doi: https://doi. org/10.1016/j.ajic.2016.11.028

44. Ream PS, Tipple AF, Salgado TA, Souza AC, Souza SM, Galdino-Junior $\mathrm{H}$, et al. Hospital housekeepers: victims of ineffective hospital waste management. Arch Environ Occup Health. 2016;71(5):273-80. doi: https://doi.org/ 10.1080/19338244.2015.1089827

45. Martins AMEBL, Costa FM, Ferreira RC, Santos PE Neto, Magalhaes TA, Sá MAB, et al. Factors associated with immunization against Hepatitis $B$ among workers of the Family Health Strategy Program. Rev Bras Enferm. [Internet]. 2015 Jan/Fev [cited Set 25, 2018];68(1): 77-84. Available from: http://www.scielo.br/pdf/reben/ v68n1/en_0034-7167-reben-68-01-0084.pdf

46. Chang $\mathrm{HH}$, Lee WK, Moon C, Choi WS, Yoon $\mathrm{HJ}$, $\mathrm{Kim} \mathrm{J}$, et al. The acceptable duration between occupational exposure to hepatitis $B$ virus and hepatitis $B$ immunoglobulin injection: Results from a Korean nationwide, multicenter study. Am J Infect Control. 2016;44(2):189-93. doi: https://doi.org/10.1016/j. ajic.2015.08.024

47. Pinelli C, Neri SN, Loffredo LCM. Dental students' reports of occupational exposures to potentially infectious biological material in a Brazilian School of Dentistry. Cad Saúde Colet. [Internet]. 2016 [cited Jan 21, 2018];24(2):162-9. Available from: http://www.scielo. $\mathrm{br} / \mathrm{pdf} / \mathrm{cadsc} / \mathrm{v24n2/1414-462X-cadsc-24-2-162.pdf}$

48. Ministério da Saúde (BR). Agência Nacional de Vigilância Sanitária. Resolução RDC no 11 de 13 de março de 2014. Dispõe sobre os Requisitos de Boas Práticas de Funcionamento para os Serviços de Diálise e dá outras providências. [Internet]. [Acesso 20 jan 2018]. Disponível em: http://portal.anvisa.gov.br/ documents/10181/2867923/(1)RDC_11_2014_COMP. pdf/5e552d92-f573-4c54-8cab-b06efa87036e

49. Neves ZCP, Tipple AFV, Mendonça KM, Souza ACS, Pereira MS. Brazilian legislation and recommendations related to occupational health and safety of health workers. Rev Eletr Enferm. [Internet]. 2017 [cited Jun 11, 2018];19:a01. Available from: https://revistas.ufg. br/fen/article/view/40427/22827

50. 50. Robotin M, Patton Y, Kansil M, Penman A, George J. Cost of treating chronic hepatitis $B$ : comparison of current treatment guidelines. World J Gastroenterol. [Internet]. 2012 [cited Jan 15, 2018];18(42):6106-13. Available from: https://www.ncbi.nlm.nih.gov/pmc/ articles/PMC3496887/pdf/WJG-18-6106.pdf

51. Banerjee S, Gunda P, Drake RF, Hamed K. Telbivudine for the treatment of chronic hepatitis B in HBeAg-positive patients in China: a health economic analysis. [Internet]. Springerplus. 2016 [cited Nov 25, 2018];5(1):1719. Available from: https://www.ncbi.nlm.nih.gov/pmc/ articles/PMC5052247/pdf/40064_2016_Article_3404.pdf 
52. Oliveira ML, Santos LMP, Silva EN. Bases metodológicas para estudos de custos da doença no Brasil. Rev Nutr. [Internet]. 2014 [Acesso 5 jun 2018];27:585-95. Disponível em: http://www.scielo.br/ pdf/rn/v27n5/1415-5273-rn-27-05-00585.pdf

53. Drummond MF, Sculpher MJ, Torrance GW, O'Brien $B J$, Stoddart GL. Methods for the economic evaluation of health care programmes. 3rd ed. Oxford: Oxford University Press; 2005. Creative Commons (CC BY). 